\title{
Finite Element Analysis of One Dimensional Bio-Heat Transfer in Human Tissue
}

\author{
Mst. Nasima Bagum ${ }^{1}$, Anup Shaha ${ }^{2}$, Mohsiu Ahmed ${ }^{3}$, \\ Choudhury Abul Anam Rashed ${ }^{4}$ \\ ${ }^{1,4}$ Assistant Professor, Department of Industrial and Production Engineering, ShahJalal University of Science \& \\ Technology.
}

\begin{abstract}
Different therapeutic treatment requires precise monitoring of bio-heat transfer of human tissue for preserving the healthy tissues near the skin surface, from burning or freezing during therapeutic application. Bio-heat transfer analysis of thermal medical problems usually has to simultaneously face the transient or spatial heating both on skin surface and in interior of the biological bodies. It is difficult to perform heat transfer analysis on complex shape of biological body by analytical solution. In this research Finite Element Method was used to analyze 1D bio-heat transfer in human tissue. Based upon the Finite Element Method a generalized computer program was developed. Solution obtained by using Finite Element Analysis was compared with analytical solution. Here it was shown that computer based approximate solution is best option to perform heat transfer analysis of complex shape.
\end{abstract}

Index Terms: - Analytical Solution, Bio-heat Transfer, Numerical Solution, Pennes Equation.

\section{INTRODUCTION}

Bio-heat transfer is the study of heat transfer in biological systems [1]. It is the study of how heat moves within the body or external to the body. The thermal therapies are based on the heat transfer in biological tissues [2]. The purpose of therapeutic application on biological body is either raising or lowering of temperature at various points in human tissue. Heat transfer is fundamental and very important process in living tissues in order to maintain an almost constant temperature. In practical field, it is difficult to evaluate accurately the thermal response of the biological tissues during therapeutic applications, because of the complex mechanisms that maintain body temperature such as- blood flow and metabolic heat generation. Therefore, it is very important to provide therapist with useful data concerning the thermal analysis of biological tissues. For example, in thermal diagnostics [3] and thermal comfort analysis [4-6], thermal parameter estimation [7-12], or burn injury evaluation [13-14], complex heating was encountered. By using Finite Element Analysis (FEA) we obtained temperature at various points in human tissue during therapeutic applications. Heat transfer was calculated by using the temperature at different nodal points. A generalized computer program is developed by using Finite Element Method for the analysis of one dimensional (1D) heat transfer in Human Tissue. The solution provided by the developed model is compared with analytical solution for validation.

\section{DESCRIPTION OF THE MODEL}

Pennes equation [15] is widely used for the analysis of heat transfer in living tissue, which describes the influence of blood flow on the temperature distribution in the tissue in terms of volumetrically distributed heat sinks or sources. The generalized 1D Pennes equation [15] can be written as

$$
\rho c \frac{\partial T}{\partial t}=K \frac{d 2 T_{0}(x)}{d x^{2}}+\omega_{b} \rho_{b} C_{b}\left[T_{a}-T_{0}(x)\right]+Q_{m}
$$

Where $\sigma, \mathrm{c}, \mathrm{k}$ are respectively the density, the specific heat, and the thermal conductivity of the tissue; their unit are respectively $\mathrm{kg} / \mathrm{m}^{3}, \mathrm{~J} / \mathrm{kg}^{\circ} \mathrm{C}, \mathrm{W} / \mathrm{m}^{\circ} \mathrm{C} ; \rho_{b}, C_{b}$ denote density and specific heat of blood; $\omega_{b}$ the blood perfusion and unit is $\mathrm{ml} / \mathrm{s} / \mathrm{ml} ; T_{a}$ arterial temperature which is treated as constant and $\mathrm{T}$ the tissue temperature in ${ }^{\circ} \mathrm{C} ; \mathrm{Q}_{\mathrm{m}}$ is the metabolic heat generation and unit is $\mathrm{W} / \mathrm{m}^{3}$. " $\rho c \frac{\partial T}{\partial \mathrm{t}}$ " is heat store by tissue, which is zero for steady-state condition. " $\mathrm{K} \frac{\mathrm{d}^{2} \mathrm{~T}_{0}(\mathrm{x})}{\mathrm{dx}^{2}}$ " is heat loss by conduction and $\omega_{b} \rho_{b} C_{b}\left[T_{a}-T_{0}(x)\right]$ is heat loss by blood perfusion. " $\mathrm{Q}_{\mathrm{m}}$ " is metabolic heat generation. The summation of heat loses is equal to metabolic heat generation for steady-state condition, where work done is negligible.

The initial steady-state temperature field for biological bodies can be obtained through solving the following equations: 


$$
\left\{\begin{array}{c}
K \frac{d^{2} T_{0}(x)}{d x^{2}}+\omega_{b} \rho_{b} C_{b}\left[T_{a}-T_{0}(x)\right]+Q_{m}=0 \\
T_{0}(x)=T_{c} \quad, \quad x=L \\
-K \frac{d T_{0}(x)}{d x}=h o\left[T_{f}-T_{0}(x)\right], x=0
\end{array}\right.
$$

Where, $T(x .0)=T_{0}(x)$ is steady-state temperature fields prior to heating, $T_{c}$ the body core temperature and often regarded as a constant, $\mathrm{h}_{0}$ the apparent physiological heat convection coefficient between the skin surface and surrounding air and is an overall contribution from natural convection and radiation, and $\mathrm{T}_{\mathrm{f}}$ the surrounding air temperature. The forced convection coefficient is applied as $h_{f}=100 \mathrm{~W} / \mathrm{m}^{2 \circ} \mathrm{C}$, while the surrounding air temperature was chosen as $\mathrm{T}_{\mathrm{f}}=25^{\circ} \mathrm{C}$ [3].

Here skin surface is defined at $\mathrm{x}=0$ while the body core at $\mathrm{x}=\mathrm{L}$. Previous research works $[12,16]$ indicate that, the interior tissue temperature usually remain a constant within a short distance such $2-3 \mathrm{~cm}$ from skin surface, therefore we use the length of domain $\mathrm{L}=3 \mathrm{~cm}$ in our research. For our analysis we made some estimation regarding tissue properties [9] which shown in table 1.

Table 1: Typical tissue properties

\begin{tabular}{|l|c|c|c|}
\hline Tissue properties & Symbol & Value & Unit \\
\hline $\begin{array}{l}\text { Thermal conductivity of } \\
\text { tissue }\end{array}$ & $K$ & 0.5 & $\mathrm{~W} / \mathrm{m}^{\circ} \mathrm{C}$ \\
\hline $\begin{array}{l}\text { Heat convection } \\
\text { coefficient between skin } \\
\text { \& surrounding }\end{array}$ & $h_{0}$ & 10 & $\mathrm{~W} / \mathrm{m}^{2}{ }^{\circ} \mathrm{C}$ \\
\hline $\begin{array}{l}\text { Force convection } \\
\text { co-efficient }\end{array}$ & $h_{f}$ & 100 & $\mathrm{~W} / \mathrm{m}^{2}{ }^{\circ} \mathrm{C}$ \\
\hline $\begin{array}{l}\text { Surrounding air } \\
\text { temperature }\end{array}$ & $T_{f}$ & 25 & ${ }^{\circ} \mathrm{C}$ \\
\hline The arterial temperature & $T_{a}$ & 37 & ${ }^{\circ} \mathrm{C}$ \\
\hline Body core temperature & $T_{c}$ & 37 & ${ }^{\circ} \mathrm{C}$ \\
\hline $\begin{array}{l}\text { Metabolic heat } \\
\text { generation }\end{array}$ & $Q_{m}$ & 33800 & $\mathrm{~W} / \mathrm{m}^{3}$ \\
\hline Specific heat of tissue & $c$ & 4200 & $\mathrm{~J} / \mathrm{kg}{ }^{\circ} \mathrm{C}$ \\
\hline Specific heat of blood & $c_{b}$ & 4200 & $\mathrm{~J} / \mathrm{kg}{ }^{\circ} \mathrm{C}$ \\
\hline Density of tissue & $\rho$ & 1000 & $\mathrm{~kg} / \mathrm{m}^{3}$ \\
\hline Density of blood & $\rho_{b}$ & 1000 & $\mathrm{~kg} / \mathrm{m}^{3}$ \\
\hline The Blood perfusion & $\omega_{b}$ & 0.0005 & $\mathrm{ml} / \mathrm{s} / \mathrm{ml}$ \\
\hline
\end{tabular}

\section{TISSUE TEMPERATURE CALCULATION}

Pennes [15] equation of 1D Bio-heat transfer in human tissue was solved using Finite Element Method by providing necessary assumption. The steps are described below.

\section{A. Boundary Value Problem}

Pennes [15] equation is reformed as a boundary value problem.

$$
\begin{gathered}
\mathrm{K} \frac{\mathrm{d}^{2} \mathrm{~T}_{0}(\mathrm{x})}{\mathrm{dx}^{2}}+\omega_{b} \rho_{b} \mathrm{C}_{\mathrm{b}}\left[\mathrm{T}_{a}-\mathrm{T}_{0}(\mathrm{x})\right]+\mathrm{Q}_{\mathrm{m}}=0 \\
\text { Or, }-\frac{\mathrm{d}}{\mathrm{dx}}\left(\mathrm{k} \frac{\mathrm{dT} \mathrm{T}_{0}(\mathrm{x})}{\mathrm{dx}}-\omega_{\mathrm{b}} \rho_{\mathrm{b}} \mathrm{C}_{\mathrm{b}}\left[\mathrm{T}_{a}-\mathrm{T}_{0}(\mathrm{x})\right]-\mathrm{Q}_{\mathrm{m}}=0\right. \\
\text { Or, }-\frac{\mathrm{d}}{\mathrm{dx}}\left(\mathrm{k} \frac{\mathrm{d} \mathrm{T}_{0}(\mathrm{x})}{\mathrm{dx}}\right)+\omega_{\mathrm{b}} \rho_{\mathrm{b}} \mathrm{C}_{\mathrm{b}} \mathrm{T}_{0}(\mathrm{x})-\left(\omega_{\mathrm{b}} \rho_{\mathrm{b}} \mathrm{C}_{\mathrm{b}} \mathrm{T}_{a}+\mathrm{Q}_{\mathrm{m}}\right)=0
\end{gathered}
$$

Thus, the above equation can be rewritten as-

Where, $\mathrm{C}=\omega_{\mathrm{b}} \rho_{\mathrm{b}} \mathrm{C}_{\mathrm{b}}, \mathrm{q}=\mathrm{C} \mathrm{T}_{a}+\mathrm{Q}_{\mathrm{m}}$

$$
-\frac{\mathrm{d}}{\mathrm{dx}}\left(\mathrm{k} \frac{\mathrm{dT}_{0}(\mathrm{x})}{\mathrm{dx}}\right)+\mathrm{CT}_{0}(\mathrm{x})-\mathrm{q}=0
$$

The boundary conditions of 1D Bio-heat transfer in human tissue are
1. $\mathrm{T}_{0}(\mathrm{x})=\mathrm{T}_{\mathrm{c}}$,
Where $\mathrm{x}=\mathrm{L}$ and
2. $-\mathrm{k} \frac{\mathrm{dT}_{0}(\mathrm{x})}{\mathrm{dx}}=\mathrm{h}_{0}\left[\mathrm{~T}_{\mathrm{f}}-\mathrm{T}_{0}(\mathrm{x})\right]$, where $\mathrm{x}=0$ 


\section{B. Mesh Generation}

Mesh is collection of elements [17]. To determine the precise monitoring of heat transfer in tissue we divide the $1 \mathrm{D}$ mesh into five elements between $\mathrm{x}=0$ and $\mathrm{x}=\mathrm{L}$ as shown in figure 1 .

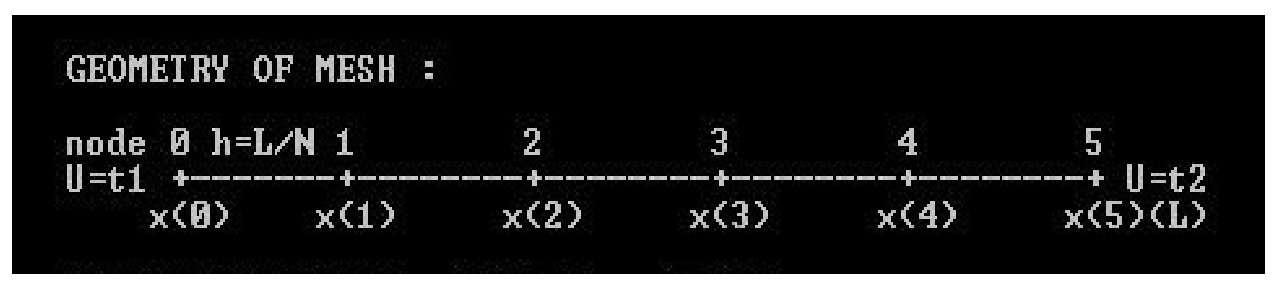

Figure 1: One-Dimensional (1D) Mesh

\section{Derivation of Element Equations}

Weak Formation

The weak from of boundary value problem is constructed by multiplying the equation (2) with weighted function w.

$$
\begin{aligned}
& 0=\int_{0}^{h_{e}} w\left(-\left[\frac{d}{d x}\left(k \frac{d T_{0}(x)}{d x}\right)\right]+c T_{0}(x)-q\right) d x \\
& 0=\int_{0}^{h_{e}}\left(-\left[w k \frac{d^{2} T_{0}(x)}{d x^{2}}\right]+c T_{0}(x) w-w q\right) d x
\end{aligned}
$$

The integration limit, $h_{e}$ represents the length of element. The equation (3) and equation (4) are simplified by using the method of integration by part.

$$
0=\int_{0}^{h_{e}}\left(k \frac{d w}{d x} \frac{d T_{0}(x)}{d x}+c w T_{0}(x)-w q\right) d x-\left[\left[w k \frac{d u}{d x}\right]_{0}^{h_{e}}\right]
$$

The weak form contains two types of expressions: those containing both $\mathrm{w}$ and $\mathrm{T} o(\mathrm{x})$ called bi-linear form, can be expressed in a single term,

$$
B\left(w, T_{0}(x)\right)=\int_{0}^{h_{e}}\left(k \frac{d w}{d x} \frac{d T_{0}(x)}{d x}+c w T_{0}(x)\right) d x
$$

Also those containing only w (but not $\mathrm{T}_{0}(\mathrm{x})$ ) is denoted by $\mathrm{l}(\mathrm{w})$, called the linear form.

Then variation statement can be expressed as-

$$
1(w)=\int_{0}^{h_{e}} w q d x+w\left(X_{A}\right) Q_{A}-w\left(X_{B}\right) Q_{B}
$$

$$
\begin{aligned}
B\left[w, T_{0}(x)\right]=l(w) \\
{\left[\mathrm { K } _ { \mathrm { ij } } \left(\mathrm{u}_{\mathrm{j}}=\mathrm{B}\left(\mathrm{w}_{\mathrm{i}}, \sum_{\mathrm{j}=0}^{\mathrm{n}} \mathrm{u}_{\mathrm{j}} \mathrm{w}_{\mathrm{i}}\right)=\sum_{\mathrm{j}=0}^{\mathrm{n}} \mathrm{u}_{\mathrm{j}} \int_{0}^{\mathrm{h}_{\mathrm{e}}}\left(\mathrm{k} \frac{\mathrm{dw} \mathrm{w}_{\mathrm{i}}}{\mathrm{dx}} \frac{\mathrm{w}_{\mathrm{j}}}{\mathrm{dx}}+\mathrm{cw}_{\mathrm{i}}\right) \mathrm{dx} \quad \text { where, } \mathrm{u}_{\mathrm{j}}=\mathrm{T}_{0}(\mathrm{x})\right.\right.} \\
{\left[K_{i j}\right]=\int_{0}^{h_{e}}\left(k \frac{d w_{i}}{d x} \frac{w_{j}}{d x}+c w_{i}\right) d x }
\end{aligned}
$$

For linear element values of weight function (w) was found by replacing the element interpolation functions, $\Psi_{\mathrm{j}}$

\section{Generation of Element Matrix}

$$
\mathrm{w}_{1}=\left(1-\frac{\mathrm{x}}{\mathrm{h}_{\mathrm{e}}}\right) \text { for node } 1 \text { and } \mathrm{w}_{2}=\frac{\mathrm{x}}{\mathrm{h}_{\mathrm{e}}} \text { for node } 2 \text {. }
$$

For getting the element matrix, value of $\mathrm{w}_{\mathrm{i}}$ was putted in equation (5) and then by integration element matrix was found.

$$
\begin{aligned}
{\left[\mathrm{K}_{\mathrm{ij}}\right] } & =\left[\begin{array}{cc}
87.53 & -81.23 \\
-81.23 & 87.53
\end{array}\right] \\
\left\{F_{i}\right\}=l\left(w_{i}\right) & =\int_{0}^{h_{e}} w_{i} q d x+w_{1} Q_{1}-w_{2} Q_{2}
\end{aligned}
$$

Finally the Matrix form of the element equation from equation (5), can be expressed as-

$$
[K]\{u\}=\{F\}
$$

\section{E. Computer Program Generation}

Element matrix $[\mathrm{K}]$ and $\{\mathrm{F}\}$ was imported to equation (6), to start program generation. The basic steps involved for computer program generation are given below.

\section{Step 1: Global Matrix Formation}

Element matrix $\mathrm{K}_{\mathrm{ij}}$ was developed for a 2 node element. To approximate $\mathrm{N}$ element mesh the $\mathrm{N}^{\text {th }}$ element matrix need to sum. This summation only occurs in node point. By developing generalize $\mathrm{C}$ program, the summation for 
$\mathrm{N}$ element mesh was obtained. After summing element matrix global matrix [G] was found for 5 elements. By putting the global matrix in (eq. 6) following output was found.

\begin{tabular}{|c|c|c|c|c|c|c|c|c|c|}
\hline 87.53 & -81.23 & 0 & 0 & 0 & 0 & & $\mathrm{~T}_{\mathrm{o}}$ & & $334.5+Q_{0}$ \\
\hline-81.23 & 175.07 & -81.23 & 0 & 0 & 0 & & $\mathrm{~T}_{1}$ & & 669.00 \\
\hline 0 & -81.23 & 175.07 & -81.23 & 0 & 0 & $\mathrm{X}$ & $\mathrm{T}_{2}$ & $=$ & 669.00 \\
\hline 0 & 0 & -81.23 & 175.07 & -81.23 & 0 & & $\mathrm{~T}_{3}$ & & 669.00 \\
\hline 0 & 0 & 0 & -81.23 & 175.07 & -81.23 & & $\mathrm{~T}_{4}$ & & 669.00 \\
\hline 0 & 0 & 0 & 0 & -81.23 & 87.53 & & $\mathrm{~T}_{5}$ & & $334.5+Q_{5}$ \\
\hline
\end{tabular}

From boundary condition

at $\mathrm{x}=\mathrm{L}$ (eq. 2), at $\mathrm{T}_{5}=37$

at $\mathrm{x}=0$ (eq. 2), at $\mathrm{Q}_{0}=\mathrm{h}_{0}\left[\mathrm{~T}_{\mathrm{f}}-\mathrm{T}_{0}\right]=\mathrm{h}_{0} \mathrm{~T}_{\mathrm{f}}-\mathrm{h}_{0} \mathrm{~T}_{0}=250-10 \mathrm{~T}_{0}$

By putting the boundary condition at equation (6) following output was found.

$$
\left|\begin{array}{cccccc}
97.53 & -81.23 & 0 & 0 & 0 & 0 \\
-81.23 & 175.07 & -81.23 & 0 & 0 & 0 \\
0 & -81.23 & 175.07 & -81.23 & 0 & 0 \\
0 & 0 & -81.23 & 175.07 & -81.23 & 0 \\
0 & 0 & 0 & -81.23 & 175.07 & -81.23 \\
0 & 0 & 0 & 0 & -81.23 & 87.53
\end{array}\right| \times\left|\begin{array}{c}
\mathrm{T}_{\mathrm{o}} \\
\mathrm{T}_{1} \\
\mathrm{~T}_{2} \\
\mathrm{~T}_{3} \\
\mathrm{~T}_{4} \\
37
\end{array}\right|=\left|\begin{array}{c}
334.5+250 \\
669.00 \\
669.00 \\
669.00 \\
669.00 \\
334.5+\mathrm{Q}_{5}
\end{array}\right|
$$

\section{Step 2: Gauss Elimination}

An algorithm in $\mathrm{C}++$ format was developed to determine, the tissue temperature at different nodal point based upon the gauss elimination of numerical solution. The result of gauss elimination is shown below.

$$
\left|\begin{array}{cccccc}
1 & -0.83 & 0 & 0 & 0 & 0 \\
0 & 1 & -0.76 & 0 & 0 & 0 \\
0 & 0 & 1 & -0.71 & 0 & 0 \\
0 & 0 & 0 & 1 & -0.69 & 0 \\
0 & 0 & 0 & 0 & 1 & -0.68 \\
0 & 0 & 0 & 0 & 0 & 1
\end{array}\right| \times\left|\begin{array}{l}
\mathrm{T}_{0} \\
\mathrm{~T}_{1} \\
\mathrm{~T}_{2} \\
\mathrm{~T}_{3} \\
\mathrm{~T}_{4} \\
37
\end{array}\right| \begin{aligned}
& 5.99 \\
& 10.75 \\
& 13.58 \\
& 15.15 \\
& 16.01 \\
& 51.21 \\
& +\mathrm{Q}_{5} / 31.92
\end{aligned} \mid
$$

\section{Step 3: Finite Element Analysis}

The value of temperature at various nodes as shown in table 1 was calculated by using the developed software and the results are shown in table 2.

Table 2: Temperature at corresponding co-ordinate of the nodal point for five elements

\begin{tabular}{|c|c|c|}
\hline $\mathrm{U}_{\mathrm{i}}$ & Node & Temperature $\left({ }^{\circ} \mathrm{C}\right)$ \\
\hline $\mathrm{T}_{0}$ & 1 & 43.26 \\
\hline $\mathrm{T}_{1}$ & 2 & 44.74 \\
\hline $\mathrm{T}_{2}$ & 3 & 44.93 \\
\hline $\mathrm{T}_{3}$ & 4 & 43.85 \\
\hline $\mathrm{T}_{4}$ & 5 & 41.34 \\
\hline $\mathrm{T}_{5}$ & 6 & 37 \\
\hline
\end{tabular}

IV. ANALYTICAL SOLUTION

The analytical solution is performed based on [18] and shown in equation 7.

$T_{0}(x)=T_{a}+\frac{Q_{m}}{\omega_{b} \rho_{b} C_{b}}+\frac{\left(T_{c}-T_{a}-\frac{Q_{m}}{\omega_{b} \rho_{b} C_{b}}\right)\left[\sqrt{A} \cosh (\sqrt{A} x)+\frac{\mathrm{h}_{0}}{k} \sinh (\sqrt{A} x)\right]}{\sqrt{A} \cosh (\sqrt{A} L)+\frac{\mathrm{h}_{0}}{k} \sinh (\sqrt{A} L)}+\frac{\frac{\mathrm{h}_{0}}{k}\left(T_{f}-T_{a}-\frac{Q_{m}}{\omega_{b} P_{b} C_{b}}\right) \sinh (\sqrt{A}(L-x))}{\sqrt{A} \operatorname{ch}(\sqrt{A} L)+\frac{\mathrm{h}_{0} 0}{k} \sinh (\sqrt{A} L)}$ 
Where, $A=\frac{\omega_{b} \rho_{b} C_{b}}{k}$

By putting the value of tissue properties in equation (7) temperature at corresponding coordinate of the nodal point for five elements are shown in table 3.

Table3: The temperature at various co-ordinates for Analytical Solution

\begin{tabular}{|c|c|c|}
\hline $\mathrm{U}_{\mathrm{i}}$ & Co-ordinate $(\mathrm{m})$ & Temperature $\left({ }^{\circ} \mathrm{C}\right)$ \\
\hline $\mathrm{T}_{0}$ & 0 & 43.19 \\
\hline $\mathrm{T}_{1}$ & 0.0006 & 44.67 \\
\hline $\mathrm{T}_{2}$ & 0.0012 & 44.86 \\
\hline $\mathrm{T}_{3}$ & 0.0018 & 43.79 \\
\hline $\mathrm{T}_{4}$ & 0.0024 & 41.3 \\
\hline $\mathrm{T}_{5}$ & 0.003 & 37 \\
\hline
\end{tabular}

\section{RESULTS AND DISCUSSION}

In this study three cases are taken for showing the significance of Finite Element Analysis and the effects of element number on finite element analysis. In case 1, two elements are taken. In case 2 , five elements are taken. And case 3 twenty elements are taken, as shown in figure2, 3 and 4 respectively.

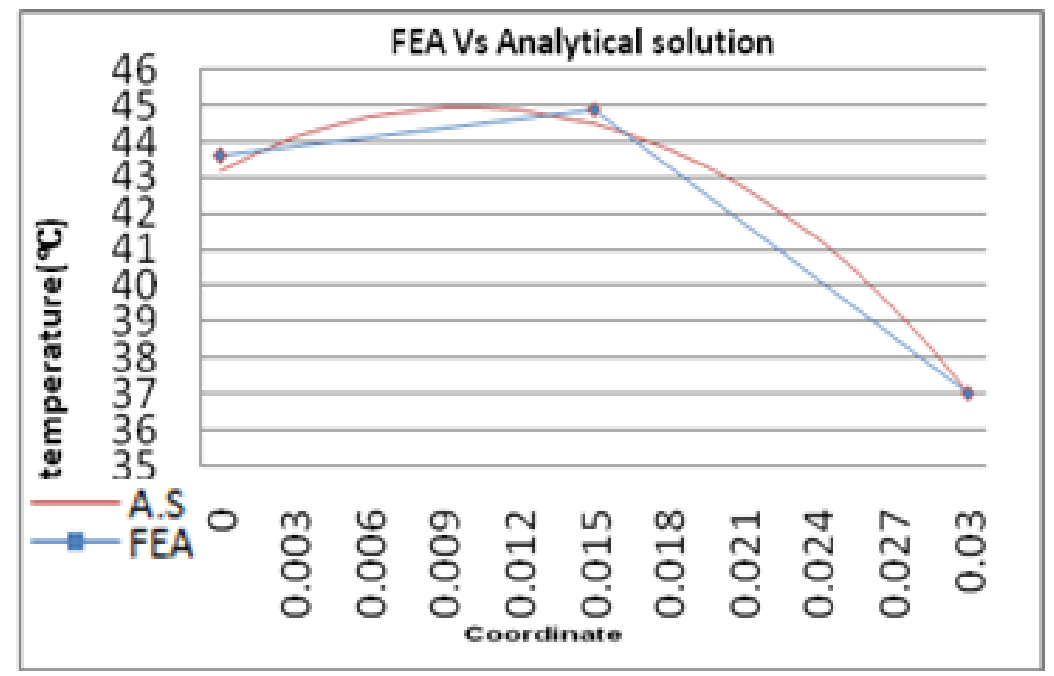

Figure 2: Temperature distribution for FEA in comparison with Analytical solution for case 1.

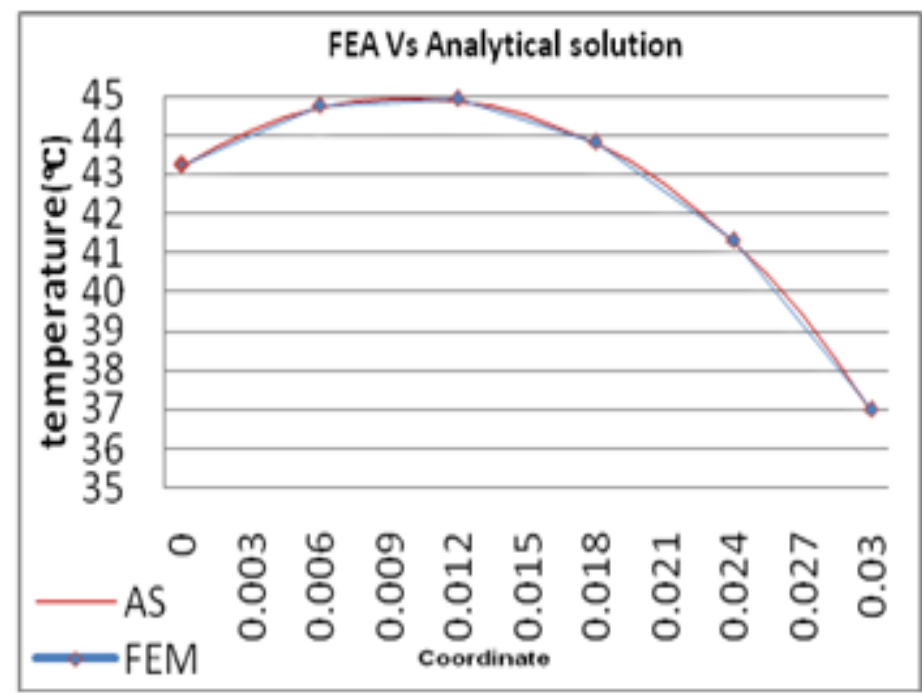

Figure 3: Temperature distribution for FEA in comparison with Analytical solution for case 2. 


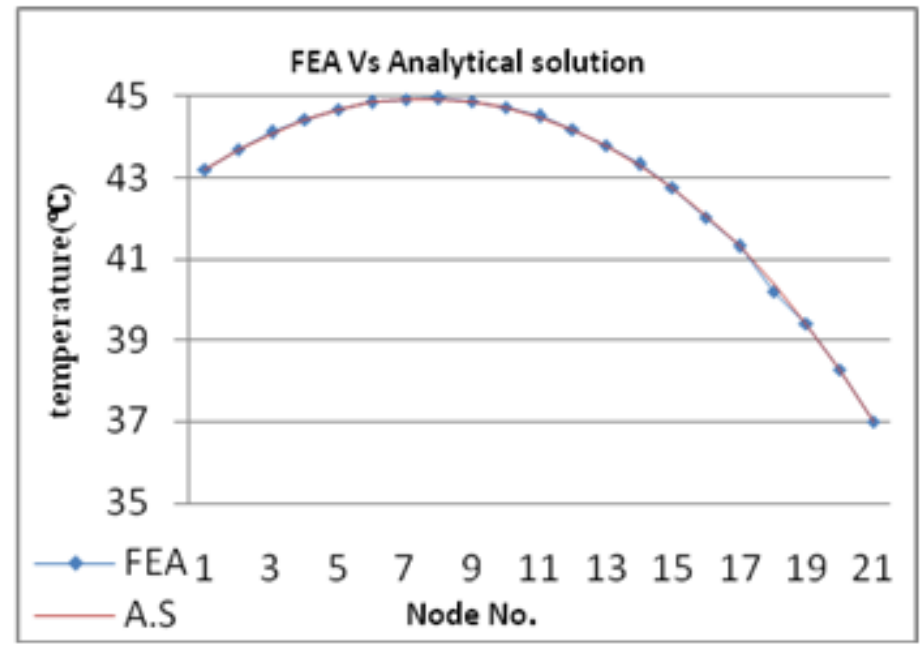

Figure 4: Temperature distribution for FEA in comparison with Analytical solution for case 3.

Figure 2, 3 and 4 shows that the precision of the result for two elements is less than the result for five elements. Also the accuracy of the result for five elements is less than the result for twenty elements. The perfection of the result of Finite Element Analysis increases with the increases of element number. By using temperature at different nodal point heat flux also can be calculated for various nodes as shown in table 4 .

Table 4: The Heat Flux at various nodes for five elements

\begin{tabular}{|c|c|c|}
\hline $\begin{array}{c}\text { Node } \\
\text { number }\end{array}$ & $\begin{array}{c}\text { Co-ordinate } \\
(\mathrm{m})\end{array}$ & Heat flux $\left(\mathrm{W} / \mathrm{m}^{2}\right)$ \\
\hline 1 & 0 & -182.56 \\
\hline 2 & 0.0006 & -123.68 \\
\hline 3 & 0.0012 & -15.68 \\
\hline 4 & 0.0018 & 89.89 \\
\hline 5 & 0.0024 & 209.4 \\
\hline 6 & 0.003 & 361.38 \\
\hline
\end{tabular}

VI. CONCLUSION

In the therapeutic treatment the nature of Bio-heat transfer is required to protect transient healthy tissue. It is difficult to find out analytical solution of complex shape like human tissue. In such case finite element method is appropriate to determine the Bio-heat transfer in human tissue. In this study a brief introduction to finite element method and finite element formulation of heat transfer in human tissue has been described. To demonstrate the situation three cases are taken for same length domain. In the case 1 two elements, case 2 five elements, case 3 twenty are taken. Result of case 3 is almost exact which validates the generated computer program. Similar procedure can be employed for the FEM formulation of other problems.

\section{REFERENCES}

[1] Website: http://en.wikipedia.org/wiki/Bioheat_transfer (last modified on 9 April 2011 at 03:33, Retrieved: July,24,2011)

[2] F. Florin, B. I. Andrei, C. M. Iulia, "Computer-aided analysis of the heat transfer in skin tissue", $3^{\text {rd }}$ WSEAS Int. Conference on finite differences - finite elements - finite volumes - boundary elements, Vol. 53, pp.53-59.

[3] J. Liu, L.X. Xu, "Boundary Information Based Diagnostics on the Thermal States of Biological Bodies," Int. J. Heat Mass Transf., Vol. 43, pp. 2827-2839, 2000.

[4] N.L. Markee, K.L. Hatch, H.I. Maibach, R.L. Barker, P. Radhakrishnaiah, S.S. Woo, "In Vivo Cutaneous and Perceived Comfort Response to Fabric. Part IV. Perceived Sensations to Three Experimental Garments Worn by Subjects Exercising in a Hot, Humid Environment," Textile Research Journal, Vol.60, pp. 561-568, 1990.

[5] S.D. Burch, S. Ramadhyani, J.T. Pearson, “Analysis of Passenger Thermal Comfort in an Automobile under Severe Winter Conditions,” ASHRAE Trans., pt. 1, ASHRAE Winter Meeting, Atlanta, pp. 247-257, 1991.

[6] E. Arens, P. Bosselmann, "Wind, Sun and Temperature. Predicting the Thermal Comfort of People in Outdoor Spaces,” Building and Environ., Vol.24, pp. 315-320, 1989.

[7] J.C. Chato, "Measurement of Thermal Properties of Growing Tumors," Ann. N.Y. Acad. Sci., Vol.335, pp. 67-85, 1980.

[8] M.M. Chen, K.R. Holmes, V. Rupinskas, “Pulse-Decay Method for Measuring the Thermal Conductivity of Living Tissues,’’ ASME J. Bio-mech. Eng., Vol.103, pp. 253-260, 1981. 
[9] A.T. Patera, B.B. Mikic, G. Eden, H.F. Bowman, "Prediction of Tissue Perfusion from Measurement of the Phase Shift Between Heat Flux and Temperature," Winter Annual Meeting of ASME, Advances in Bioengineering, pp. 187-191, 1979.

[10] P.A. Patel, J.W. Valvano, J.A. Pearce, S.A. Prahl, C.R. Denham, “'A Self-Heated Thermistor Technique to Measure Effective Thermal Properties from the Tissue Surface," ASME J. Biomech. Eng., Vol.109, pp. 300-315,1987.

[11] G.T. Anderson, J.W. Valvano, R.R. Santos, "Self-heated Thermistor Measurements of Perfusion," IEEE Trans. Biomed. Eng., Vol.39, pp. 877-885,1992.

[12] J. Liu, L.X. Xu, "Estimation of Blood Perfusion Using Phase Shift in Temperature Response to Sinusoidal Heating at the Skin Surface," IEEE Trans. Biomed. Eng., Vol.46, pp. 1037-1043, 1999.

[13] D.A. Torvi, J.D. Dale, “A Finite Element Model of Skin Subjected to a Flash Fire,” ASME J. Biomech. Eng., Vol. 116, pp. 250-255, 1994.

[14] K.R. Diller, "Modeling of Bioheat Transfer Processes at High and Low Temperatures,' Adv. Heat Transfer, Vol. 22, pp. 157-357, 1992.

[15] H.H. Pennes, "Analysis of Tissue and Arterial Blood Temperatures in the Resting Human Forearm”, J. Appl. Physiol., Vol. 1, pp. 93-122, 1948.

[16] S. Weinbaum, L.M. Jiji, D.E. Lemons, "Theory and Experiment for the Effect of Vascular Microstructure on Surface Tissue Heat Transfer-Part I: Anatomical Foundation and Model Conceptualization," ASME J. Biomech. Eng., Vol. 106, pp. 321-330,1984.

[17] K.R. Holmes, K. R., "Biological Structures and Heat Transfer", Allerton Workshop on the Future of Biothermal Engineering, 1997.

[18] D. Zhong-Shan, L. Jing, "Analytical study on bio-heat transfer problems with spatial or transient heating on skin surface or inside biological bodies". Journal of Biomechanical Engineering, [DOI: 10.1115/1.1516810], 2002.

\section{AUTHOR BIOGRAPHY}

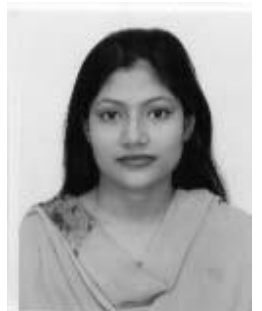

Mst. Nasima Bagum is an Assistant Professor in the Department of Industrial and Production Engineering in ShahJalal University of Science and Technology, Sylhet-3114, Bangladesh. She received B.Sc. Engineering on Industrial and Production Engineering from ShahJalal University of Science and Technology (SUST), Bangladesh and M.Sc. in Industrial Engineering from Bangladesh University of Engineering and Technology (BUET). Her research interest includes Operations Management, Sustainable Manufacturing, Heat and Mass Transfer. She has published various articles in the international journals such as International Journal of Industrial and Systems Engineering; International Journal of Scientific and Engineering Research; Asian Journal of Management, Science \& Engineering; Review of General Management; Journal of Engineering and Technology. Her research has been presented in quite a number of international conferences including Conference on Industrial Engineering and Operations Management (IEOM), Conference on Engineering Research, Innovation and Education (CERIE) etc.

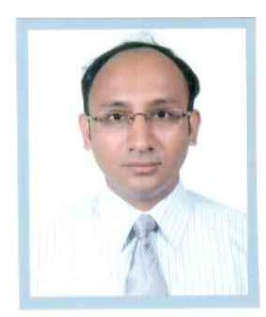

Choudhury Abul Anam Rashed is an Assistant Professor in the Department of Industrial and Production Engineering in ShahJalal University of Science \& Technology, Sylhet, Bangladesh. He completed B.Sc Engineering on Industrial and production Engineering from ShahJalal University of Science \& Technology (SUST) and M.Sc Engineering on Industrial and Production Engineering from Bangladesh University of Engineering \& Technology (BUET). He is interested in the field of Innovative Production Processes and Operations Management. He has published various articles in International Journal of Supply Chain Management, International Journal of Scientific and Engineering Research, Asian Journal of Management Science \& Education, Asian Journal of Energy and Environment, Review of General Management, International Journal of Logistics and Supply Chain Management, Journal of Engineering and Technology. His research has been presented in quite a number of international conferences including Conference on Industrial Engineering and Operations Management (IEOM), Conference on Engineering Research, Innovation and Education (CERIE) etc. 